\title{
Tanshinone IIA induces apoptosis in human lung cancer A549 cells through the induction of reactive oxygen species and decreasing the mitochondrial membrane potential
}

\author{
TSUNG-LANG CHIU ${ }^{1,3}$ and CHIN-CHENG SU ${ }^{2,4}$ \\ ${ }^{1}$ Institute of Medical Sciences; ${ }^{2}$ Tzu-Chi University, 701, sec. 3, Chung-Yang Road, Hualien 97004; \\ ${ }^{3}$ Division of Neuro-Oncology, Neuro-Medical Scientific Center; ${ }^{4}$ Division of General Surgery, \\ Buddhist Tzu-Chi General Hospital, 707, sec. 3, Chung-Yang Road, Hualien 97004, Taiwan, R.O.C.
}

Received August 17, 2009; Accepted October 16, 2009

DOI: 10.3892/ijmm_00000335

\begin{abstract}
Tanshinone IIA (Tan-IIA) is extracted from Danshen and known to inhibit proliferation and induce apoptosis in many cancer cells. We aimed to elucidate its anticancer activity and molecular mechanism in human lung cancer A549 cells. The cytotoxicity of Tan-IIA in A549 cells were measured by the MTT assay. The effects of Tan-IIA on the cell cycle, mitochondrial membrane potential (MMP), calcium and reactive oxygen species (ROS) released in A549 cells were detected by flow cytometry. The protein expressions of p53, Bax, Bcl-2 and B-actin in A549 cells were tested by Western blotting. The proliferative rates of A549 cells were obviously inhibited by Tan-IIA in a dose- and timedependent manner. The results of FACS showed that the sub-G1 phase was increased when A549 cells were cultured with various concentrations of Tan-IIA (control, 2.5, 5 and $10 \mu \mathrm{g} / \mathrm{ml}$ ) for $48 \mathrm{~h}$. Tan-IIA induced the production of ROS, $\mathrm{Ca}^{+2}$ and decreased MMP. The outcome of Western blotting showed that protein expressions of p53 and bax were increased, but proto-oncogene bcl-2 was notably decreased, after culturing with Tan-IIA $(5 \mu \mathrm{g} / \mathrm{ml})$ for 6,12 and $24 \mathrm{~h}$. Tan-IIA inhibited the proliferation of non-small cell lung cancer A549 cells, possibly by decreasing the MMP and inducing apoptosis due to the induction of a higher ratio of $\mathrm{Bax} / \mathrm{Bcl}-2$.
\end{abstract}

\section{Introduction}

Lung cancer remains deadly, prevalent and costly to patients and society. According to a 2004 report from the 'People's Health Bureau of Taiwan', lung cancer is the leading cause of cancer related deaths in Taiwan. Lung cancer is also the leading

Correspondence to: Dr Chin-Cheng Su, Division of General Surgery, Breast-Medicine center, Buddhist Tzu Chi General Hospital, 707, sec. 3, Chung-Yang Road, Hualien City 97004, Taiwan, R.O.C.

E-mail: succ.maeva@msa.hinet.net

Key words: Tanshinone IIA, A549 cells, apoptosis, mitochondrial membrane potential, reactive oxygen species cause of cancer-related morbidity and mortality in Western countries (1). Consequently, it has become a significant public health problem. However, chemotherapeutic treatment for lung cancer is still unsatisfactory. There is clearly an ongoing need for more effective treatments. Alternative medicines offer likely therapeutic agents to treat a large variety of malignant cancers. Tanshinone IIA (Tan-IIA; $\mathrm{C}_{19} \mathrm{H}_{18} \mathrm{O}_{3}$ ) was extracted from Danshen, Salviae Miltiorrhizae Radix $(2,3)$, which is widely adopted and prescribed in traditional Chinese medicine to treat cardiovascular diseases (4-6). It was well documented that Tan-IIA possesses anti-inflammatory activities $(7,8)$ and anti-oxidant properties $(9,10)$. In addition, previous studies have also demonstrated that Tan-IIA causes significant growth inhibition and apoptosis induction in human leukemia cells (11), breast cancer MDA-MB-231cells (12), colon cancer colo205 cells (13) and hepatocellular carcinoma cells (14). However, it is still unclear whether Tan-IIA has the ability to induce cell growth reduction and apoptosis in human lung cancer cells. In the present study, we investigated the roles of Tan-IIA in inducing proliferation inhibition and apoptosis-associated molecular protein expression in human non-small cell lung cancer A549 cells.

\section{Materials and methods}

Chemicals and reagents. Tan-IIA (molecular formula, $\mathrm{C}_{19} \mathrm{H}_{18} \mathrm{O}_{3}$; $>96 \%$ HPLC) was purchased from Herbasin Co. (Shenyang, China). Aprotinin, antipain, sodium deoxycholate, leupeptin, propidium iodide (PI), sodium orthovanadate, Triton X-100, Tris- $\mathrm{HCl}$, ribonuclease-A and MTT [3-(4,5)-dimethylthiahiazo (-z-y1)-3,5-di-phenytetrazolium bromide] were obtained from Sigma Chemical Co. (St. Louis, MO, USA). Dimethyl sulfoxide (DMSO), potassium phosphates and TE buffer were purchased from Merck Co. (Darmstadt, Germany). RPMI1640 medium, fetal bovine serum (FBS), penicillin-streptomycin, trypsin-EDTA, and glutamine were obtained from Gibco BRL (Grand Island, NY, USA). 10X SDS-PAGE running buffer, Tris, Tween-20, SDS, 5X TBE buffer were obtained from Amresco (St. Louis, MO, USA). BioMax Flim was obtained from Kodak. DioC6 (84715) and $\mathrm{H}_{2} \mathrm{DCFDA}_{(\mathrm{C} 6827)}$ were obtained from Biocompare, USA). Anti- 3 -actin (MAB1501; Chemicon), anti-p21 (MS-891-PO; NeoMarkers) 
anti-p53 (MS-256-PO; NeoMarkers), anti-Cytochrome c (cat\#pc323; Calbiochem), anti-Bcl-2 (N-19-sc-492; Santa Cruz Biotechnology, Inc), anti-Bax (N-19-sc-492; Santa Cruz Biotechnology, Inc). Goat anti-mouse IgG (HRP) horseradish peroxidase conjugated antibody (AP124P), was obtained from Chemicon.

Human lung cancer cell line (A549 cells). The human lung cancer A549 cells were obtained from the Food Industry Research and Development Institute (Hsinchu, Taiwan). The A549 cells were placed into $25-\mathrm{cm}^{2}$ tissue culture flasks and maintained in RPMI-1640 contained with $10 \%$ heat-inactivated fetal bovine serum (FBS) (Gibco BRL), $100 \mathrm{U} / \mathrm{ml}$ penicillin and $100 \mu \mathrm{g} / \mathrm{ml}$ streptomycin and grown at $37^{\circ} \mathrm{C}$ in a humidified atmosphere of $95 \%$ air and $5 \% \mathrm{CO}_{2}$. All data presented in this report are from at least three independent experiments.

The effects of Tan-IIA on viability of A549 cells. The A549 cells were plated in a density of $1 \times 10^{5}$ cells per well and grown for $24 \mathrm{~h}$. Various concentrations of Tan-IIA were added and cells were grown for 24,48 and $72 \mathrm{~h}$, while only adding DMSO $0.2 \%$ (solvent) for the control regimen. For determining cell viability, after 24,48 and $72 \mathrm{~h}$ of culture, viability was evaluated by MTT assay (15) in triplicate. Briefly, A549 cells were seeded in a 6-well plate at a density of $1 \times 10^{5}$ cells/well and allowed to adhere overnight. After removing the medium, 2,000 $\mu \mathrm{l}$ of fresh medium per well, containing $10 \mathrm{mM}$ HEPES was then added and $200 \mu 1$ of 3-(4,5-dimethylthiazol-2-yl)2,5-diphenyl-2H-tetrazolium bromide (MTT) was added to the wells and the plate was incubated for $30 \mathrm{~min}$ at $37^{\circ} \mathrm{C}$ in the dark. Medium was removed and 1,000 $\mu 1$ DMSO was added to the wells. Absorbance was measured using an ELISA plate reader at $590 \mathrm{~nm}$.

Cell cycle analysis for A549 cells treated with Tan-IIA by flow cytometry assay. The percentage of cells in sub-G1, G0/G1, S and $\mathrm{G} 2 / \mathrm{M}$ phases were determined by flow cytometry as described previously (16). Briefly, A549 cells (1x106/10 cm dishes) were incubated with various concentrations of Tan-IIA $(0,2.5,5$ and $10 \mu \mathrm{g} / \mathrm{ml})$ for $48 \mathrm{~h}$ before cells were harvested by centrifugation. After being harvested, cells were washed with PBS, then fixed gently (drop by drop) in $70 \%$ ethanol (in PBS) in ice overnight and resuspended in PBS containing $40 \mu \mathrm{g} / \mathrm{ml}$ PI, $0.1 \mathrm{mg} / \mathrm{ml}$ RNase (Sigma) and $0.1 \%$ Triton X-100. After $30 \mathrm{~min}$ at $37^{\circ} \mathrm{C}$ in the dark, cells were analyzed with flow cytometry (Becton-Dickinson, San Jose, CA, USA) equipped with an argon laser at $488 \mathrm{~nm}$. Then, cell cycle and apoptosis were determined and analyzed using the ModFit software. The average of the percentage of each phase in the cell cycle was representative of three independent experiments.

Flow cytomertry detection of ROS in A549 cells after treatment with Tan-IIA. The levels of ROS in A549 cells were examined and determined by flow cytometry (Becton Dickinson FACS Calibur) as described previously (17). Briefly, 2, 7-dichlorodihydrofluorescein diacetate (DCFH-DA, Biocompare, USA) was used for staining. Cells were treated with or without Tan-IIA for different durations $(0,6,12$, and $24 \mathrm{~h})$ to detect changes of ROS. Cells were harvested and washed twice, resuspended in $500 \mu 1$ of 2,7-dichlorodihydrofluorescein diacetate solution
$(10 \mu \mathrm{M})$, incubated at $37^{\circ} \mathrm{C}$ for $30 \mathrm{~min}$ and analyzed by flow cytometry.

Flow cytometry detection of $\mathrm{Ca}^{2+}$ concentrations in A549 cells after treatment with Tan-IIA. The $\mathrm{Ca}^{2+}$ levels in A549 cells were determined by flow cytometry as described previously (17). Briefly, using Indo 1/AM (Calbiochem; La Jolla, CA, USA) for staining. Cells were pre-treated with or without Tan-IIA for different durations (0, 6, 12, and $24 \mathrm{~h})$, harvested and washed twice, then resuspended in Indo 1/AM $(3 \mu \mathrm{g} / \mathrm{ml})$, incubated at $37^{\circ} \mathrm{C}$ for $30 \mathrm{~min}$, and the changes of $\mathrm{Ca}^{2+}$ concentrations were analyzed by flow cytometry.

Flow cytometry detection of MMP in A549 cells after treatment with Tan-IIA. The MMP levels in A549 cells were determined by flow cytometry as described previously (17). Briefly, DiOC6 (4 mol/l, Biocompare) was used for staining. Cells were treated with or without Tan-IIA for different durations $(0,6,12$, and $24 \mathrm{~h})$, harvested and washed twice, resuspended in $500 \mu \mathrm{l}$ of DiOC6 $(4 \mathrm{~mol} / \mathrm{l})$, incubated at $37^{\circ} \mathrm{C}$ for $30 \mathrm{~min}$ and the changes of MMP were analyzed by flow cytometry.

Western blotting for examination of the effect of Tan-IIA on p53, Bcl-2, Bax, and Cytochrome c levels in A549 cells. Total proteins were collected from A549 cells after treatment with or without various concentrations of Tan-IIA for $0,6,12$, and $24 \mathrm{~h}$ before p53, Bcl-2, Bax, and Cytochrome c (Cyto-c) levels were examined by sodium dodecylsulfate polyacrylamide gel electrophoresis (SDS-PAGE) and Western blotting, as described previously $(12,18)$.

DNA fragmentation electrophoresis analysis from A549 cells co-treated with different concentrations of Tan-IIA. A549 cells were plated in 6-well plates at a density of $5 \times 10^{6}$ cells/ well and grown for $24 \mathrm{~h}$. Then different concentrations of Tan-IIA $(0,2.5,5$ and $10 \mu \mathrm{g} / \mathrm{ml})$ were added, while only adding DMSO (solvent) for the control regimen and grown at $37^{\circ} \mathrm{C}$, in humidified $5 \% \mathrm{CO}_{2}$ and $95 \%$ air for $24 \mathrm{~h}$. The DNA was prepared using Genome DNA isolation kit protocol (BIO 101, La Jolla, CA, USA). DNA fragmentation electrophoresis assay was used as described previously (19). We ran DNA on a $1.2 \%$ agarose gel containing EtBr on the power supply to 75 volts. It was visualized on a UV Trans illuminator.

Statistical analysis. Values are presented as percentage \pm SD of control. The Student's t-test was used to analyze the statistical significance between the Tan-IIA treated and control groups. A p-value $<0.05$ was considered significant for all tests.

\section{Results}

Effects of Tan-IIA on cell viability. To investigate the inhibitory effect of Tan-IIA on cell growth of human lung cancer A549 cells, A549 cells were cultured and exposed to Tan-IIA at concentrations of $1,2,3,4$ and $5 \mu \mathrm{g} / \mathrm{ml}$ for 24,48 and $72 \mathrm{~h}$. The cytotoxicity of Tan-IIA in A549 cells was determined using the MTT assay. The percentages of viable cells relative to control were $85.94 \pm 0.35,46.96 \pm 0.4,21.27 \pm 0.12,20.4 \pm 0.1$, $17.97 \pm 0.15 \%$, respectively, when cultured with various concentrations of Tan-IIA $(1,2,3,4$ and $5 \mu \mathrm{g} / \mathrm{ml})$ for $24 \mathrm{~h}$. The 


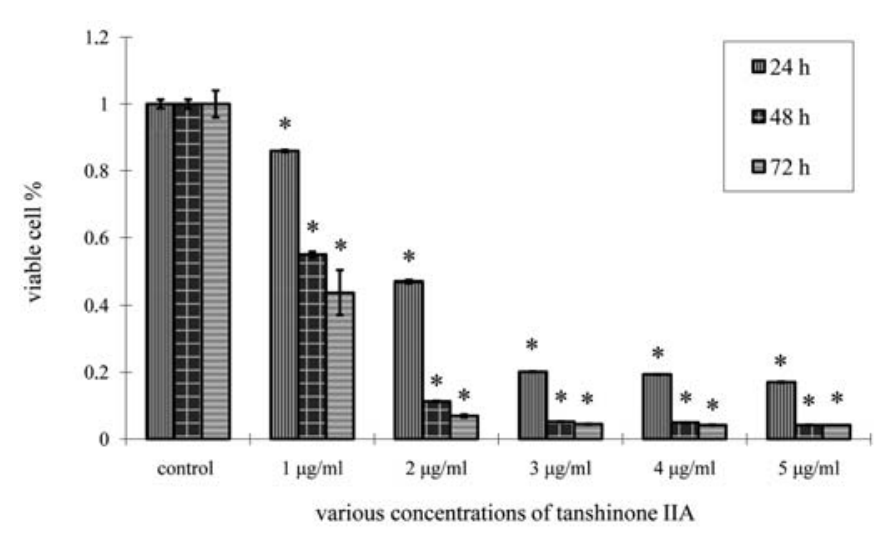

Figure 1. A549 cells were treated with increased Tanshinone IIA concentrations of $0,1,2,3,4$ and $5 \mu \mathrm{g} / \mathrm{ml}$ for 24,48 and $72 \mathrm{~h}$. The cytotoxicity of Tanshinone IIA in A549 cells was determined using the MTT assay as described in Materials and methods. Tanshinone IIA significantly inhibited A549 cell growth. Each point is the mean \pm SD of three experiments. ${ }^{*} \mathrm{P}<0.05$.
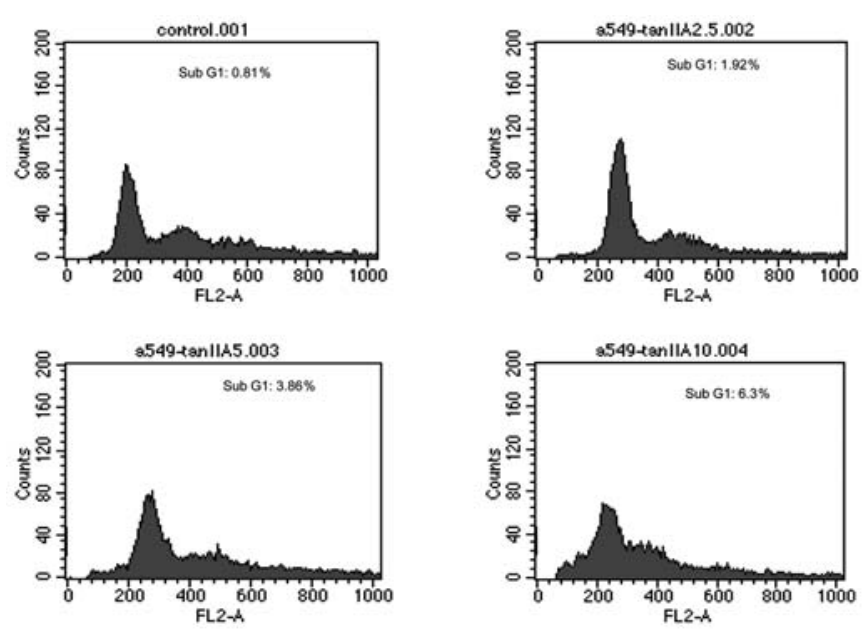

Figure 2. A549 cells were exposed to Tanshinone IIA concentrations of control, $2.5,5$ and $10 \mu \mathrm{g} / \mathrm{ml}$ for $48 \mathrm{~h}$. Cells were harvested and cell cycle analysis was performed by flow cytometry as described in Materials and methods. The percentages of cells in the sub-G1 phase exhibited a significant increase after treatment with $2.5,5$ and $10 \mu \mathrm{g} / \mathrm{ml}$ of Tanshinone IIA for $48 \mathrm{~h}$.

percentages of viable cells relative to control were $54.95 \pm 0.86$, $11.23 \pm 0.14,5.14 \pm 0.12,4.91 \pm 0.06$ and $4.18 \pm 0.06 \%$, respectively, when cultured with various concentrations of Tan-IIA $(1,2,3,4$ and $5 \mu \mathrm{g} / \mathrm{ml})$ for $48 \mathrm{~h}$. The percentages of viable cells relative to control were $43.7 \pm 6.59,6.9 \pm 0.4$, $4.44 \pm 0.12,4.18 \pm 0.12$ and $4.13 \pm 0.00 \%$ respectively, when cultured with various concentrations of Tan-IIA (1, 2, 3, 4 and $5 \mu \mathrm{g} / \mathrm{ml}$ ) for $72 \mathrm{~h}$. The $\mathrm{IC}_{50}$ concentrations for Tan-IIA to treat A549 cells for different durations (24, 48 and $72 \mathrm{~h}$ ) were 2, 1.5 and $1 \mu \mathrm{g} / \mathrm{ml}$. Results showed that Tan-IIA exhibited remarkable inhibition against the growth of A549 cells in a time- and dose-dependent manner (Fig. 1). BALB 3 T3 fibroblast cells were used for positive control. The $\mathrm{IC}_{50}$ concentrations for Tan-IIA to treat BALB3T3 cells for different durations (24, 48 and $72 \mathrm{~h}$ ) were $5.58,6.08$ and $9.77 \mu \mathrm{g} / \mathrm{ml}$ in our previous study (13).
A
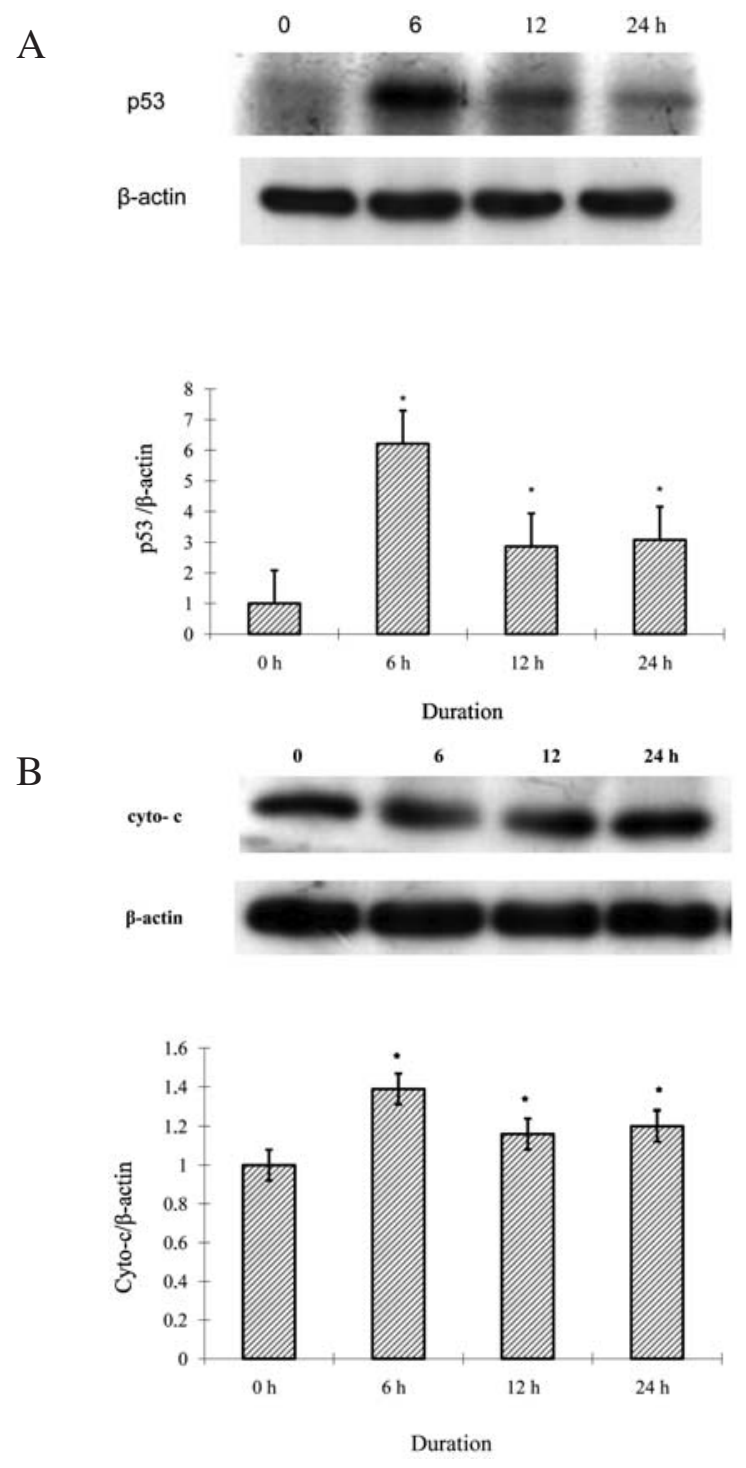

Figure 3. Protein expression of p53 and Cytochrome c (Cyto-c) in A549 cells after exposure to Tan-IIA. A549 cells $\left(5 \times 10^{6} / \mathrm{ml}\right)$ were treated with Tan-IIA $(2 \mu \mathrm{g} / \mathrm{ml})$ for different durations $(0,6,12$ and $24 \mathrm{~h})$ before being harvested by centrifugation. Total protein was prepared and determined as described in Materials and methods. Levels of (A) p53 and (B) Cyto-c expression were estimated by Western blotting as described in Materials and methods. Protein expression of p53 (A) and Cyto-c (B) was significantly increased after treatment with Tan-IIA for $6 \mathrm{~h}$. Each point is the mean $\pm \mathrm{SD}$ of three experiments. ${ }^{*} \mathrm{P}<0.05$.

Effects of Tan-IIA on cell cycle. In order to determine the effect of Tan-IIA on cell growth and apoptosis in A549 cells, cell cycle distribution was analyzed by flow cytometry. When A549 cells were treated with Tan-IIA $(0,2.5,5$ and $10 \mu \mathrm{g} / \mathrm{m})$ for $48 \mathrm{~h}$, the percentage of cells in the sub-G1 phase increased from 0.81 to $1.92,3.86$ and $6.3 \%$, respectively (Fig. 2). Results showed that apoptosis increased after A549 cells were treated with various concentrations of Tan-IIA $(0,2.5,5$ and $10 \mu \mathrm{g} / \mathrm{m})$ for $48 \mathrm{~h}$.

Western blot investigation of the effect of Tan-IIA on p53, Bax, Bcl-2, and Cytochrome c levels. Protein expression of p53 and Cyto-c in A549 cells after exposure to Tan-IIA. A549 cells $\left(5 \times 10^{6} / \mathrm{ml}\right)$ were treated with Tan-IIA $(2 \mu \mathrm{g} / \mathrm{ml})$ for 
A
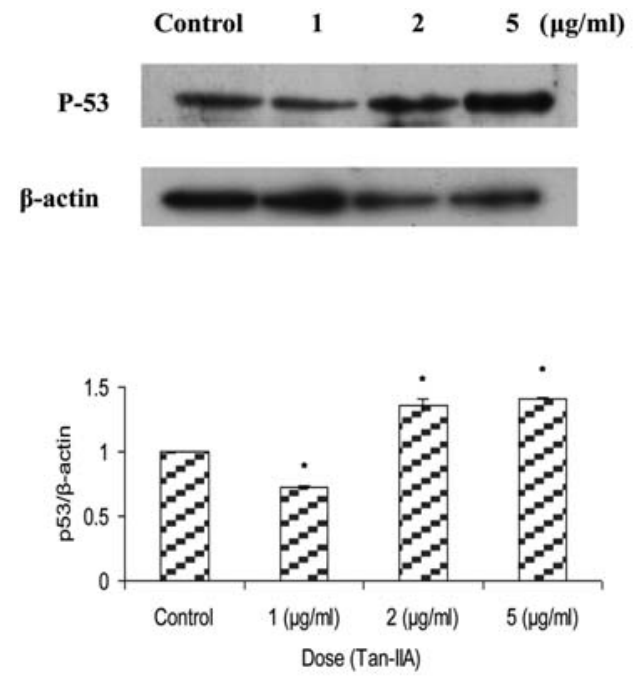

B
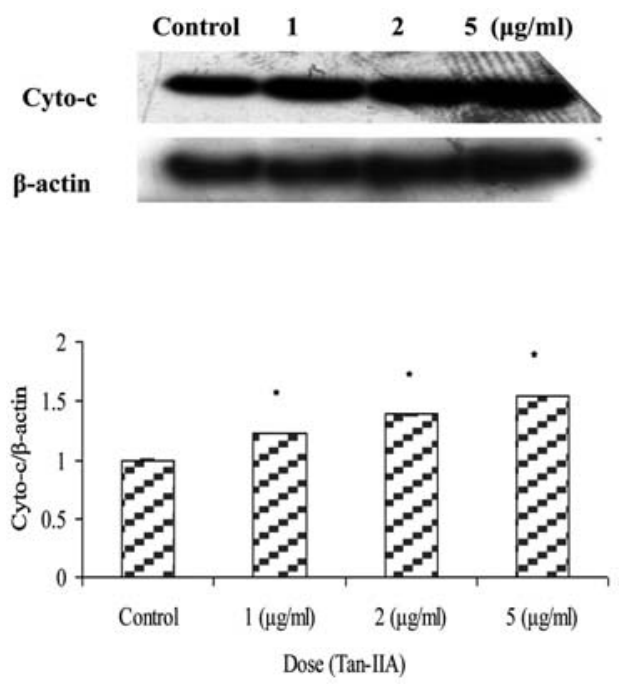

Figure 4. Representative Western blot showing changes on the levels of p53 (A) and Cyto-c (B) in A549 cells after exposure to Tan-IIA. The A549 cells $\left(5 \times 10^{6} / \mathrm{ml}\right)$ were treated with various concentrations $(1,2$ and $5 \mu \mathrm{g} / \mathrm{ml})$ of Tan-IIA for $24 \mathrm{~h}$, then cytosolic fraction and total protein were prepared and determined as described in Materials and methods. This was followed by evaluation of the levels of p53 (A) and Cyto-c (B) expressions which were estimated by Western blotting as described in Materials and methods. Tan-IIA increased the protein expression of p53 (A) and Cyto-c (B) at the concentrations of 2 and $5 \mu \mathrm{g} / \mathrm{ml}$ for $24 \mathrm{~h}$. Each point is the mean $\pm \mathrm{SD}$ of three experiments. ${ }^{*} \mathrm{P}<0.05$.

different durations $(0,6,12$ and $24 \mathrm{~h})$ before being harvested by centrifugation. Total protein was prepared and determined as described in Materials and methods. Levels of p53 and Cyto-c expression were estimated by Western blotting as described in Materials and methods. Protein expression of p53 (Fig. 3A) and Cyto-c (Fig. 3B) was significantly increased after treatment with Tan-IIA for $6 \mathrm{~h}$. Representative Western blotting showed changes on the levels of p53 and Cyto-c in A549 cells after exposure to Tan-IIA. The A549 cells $\left(5 \times 10^{6} / \mathrm{ml}\right)$ were treated with various concentrations of Tan-IIA $(1,2$ and $5 \mu \mathrm{g} / \mathrm{ml}$ ) for $24 \mathrm{~h}$, then total protein was prepared and determined as described in Materials and methods. The levels of p53 and Cyto-c expressions were estimated by Western blotting. Tan-IIA increased the protein expression of p53 (Fig. 4A) and Cyto-c (Fig. 4B) at the concentrations of 2 and $5 \mu \mathrm{g} / \mathrm{ml}$ for $24 \mathrm{~h}$. The protein expressions of Bax and Bcl-2 in
A
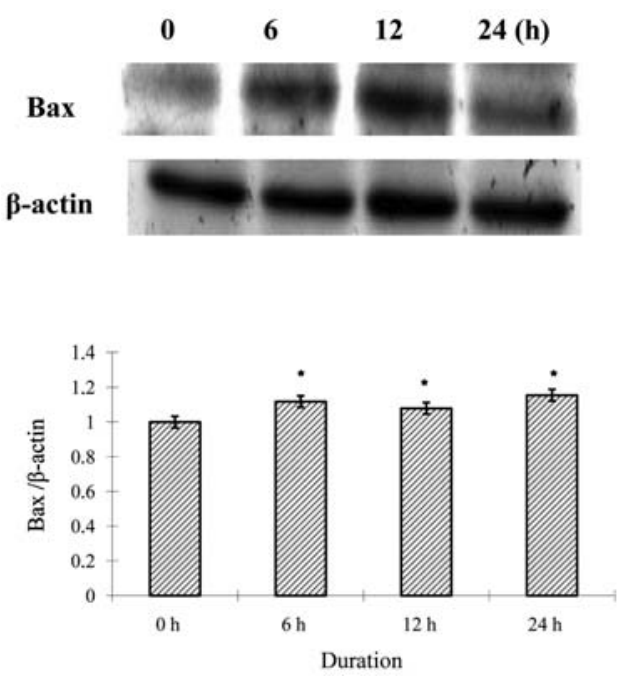

B
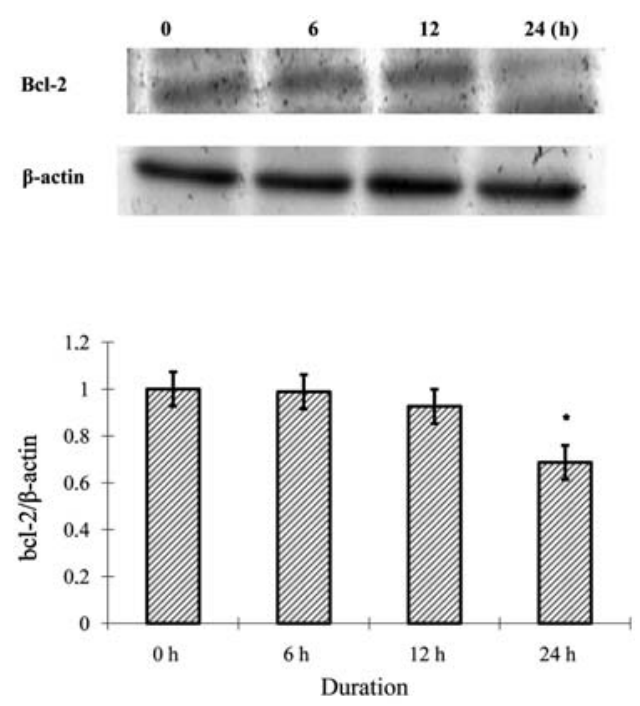

Figure 5. Protein expression of Bax and Bcl-2 in A549 cells after exposure to Tan-IIA. A549 cells $\left(5 \times 10^{6} / \mathrm{ml}\right)$ were treated with Tan-IIA $(2 \mu \mathrm{g} / \mathrm{ml})$ for different durations $(0,6,12$ and $24 \mathrm{~h})$ before being harvested by centrifugation. Total protein was prepared and determined as described in Materials and methods. Levels of (A) Bax and (B) Bcl-2 expression were estimated by Western blotting as described in Materials and methods. Protein expression of Bax (A) was significantly increased after treatment with Tan-IIA for 6, 12 and $24 \mathrm{~h}$. The protein expression of Bcl-2 (B) was significantly decreased after treatment with Tan-IIA for $24 \mathrm{~h}$. Each point is the mean $\pm \mathrm{SD}$ of three experiments. ${ }^{*} \mathrm{P}<0.05$.

A549 cells were exposed to Tan-IIA. A549 cells $\left(5 \times 10^{6} / \mathrm{ml}\right)$ were treated with Tan-IIA $(2 \mu \mathrm{g} / \mathrm{ml})$ for different durations $(0,6,12$ and $24 \mathrm{~h})$ before being harvested by centrifugation. Total protein was prepared and determined as described in Materials and methods. Levels of Bax and Bcl-2 expression were estimated by Western blotting. The protein expression of Bax (Fig. 5A) was significantly increased after treatment with Tan-IIA for 6,12 and $24 \mathrm{~h}$. The protein expression of Bcl-2 (Fig. 5B) was significantly decreased after treatment with Tan-IIA for $24 \mathrm{~h}$.

Effects of Tan-IIA on the production of ROS of A549 cells. When A549 cells were treated with Tan-IIA $(2 \mu \mathrm{g} / \mathrm{m})$ for different durations $(0,6,12$ and $24 \mathrm{~h})$, the ROS increasing percentages were $1.20 \pm 0.58,12.35 \pm 2.12,67.62 \pm 5.67$ and $83.17 \pm 3.21 \%$, respectively. Increasing time of incubation led 
A
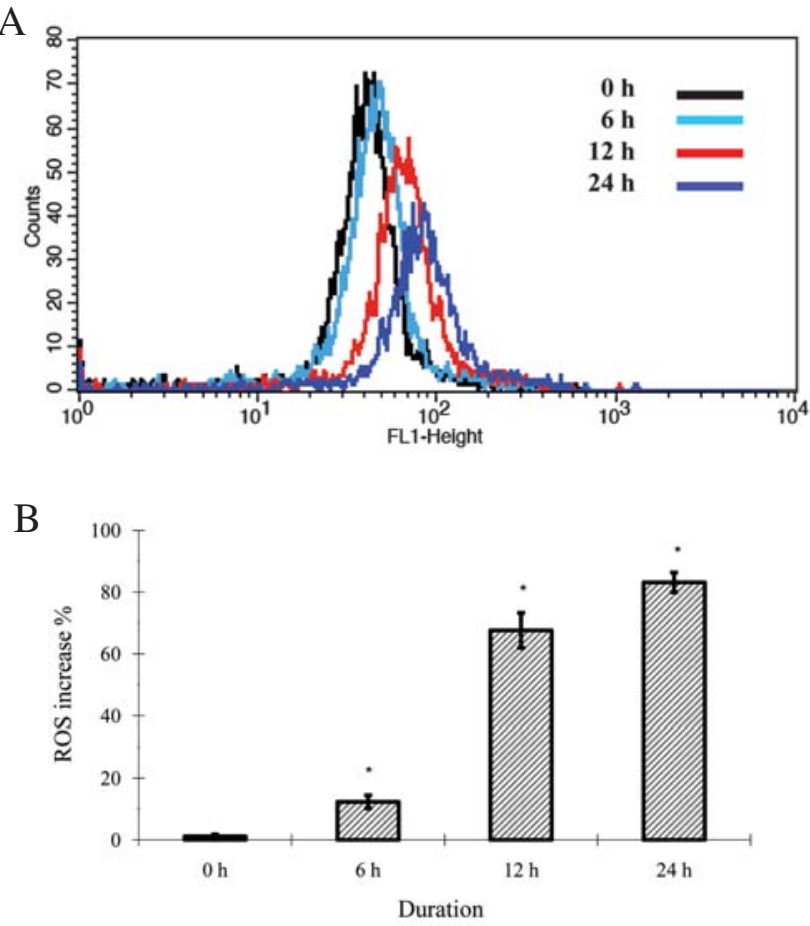

Figure 6. Effects of Tan-IIA on the production of ROS of A549 cells. A549 cells were treated with Tan-IIA $(2 \mu \mathrm{g} / \mathrm{ml})$ for different durations $(0,6,12$ and $24 \mathrm{~h})$. ROS was evaluated as described in Materials and methods. Increasing ROS percentages were $1.20 \pm 0.58,12.35 \pm 2.12,67.62 \pm 5.67$ and $83.17 \pm 3.21 \%$, respectively. Increasing the time of incubation led to an increase in the level of ROS in the examined A549 cells. Each point is the mean $\pm \mathrm{SD}$ of three experiments. ${ }^{*} \mathrm{P}<0.05$.

A

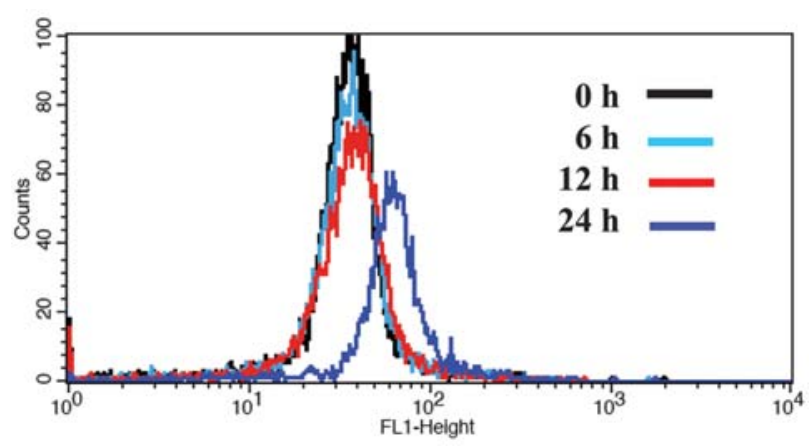

B

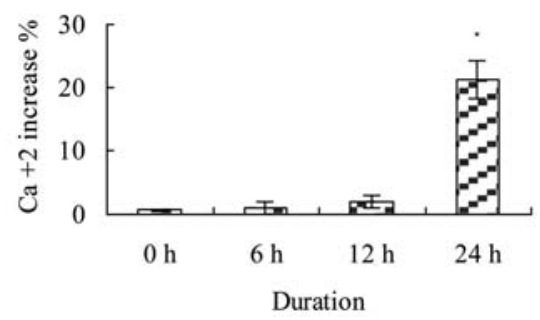

Figure 7. Effects of Tan-IIA on the production of $\mathrm{Ca}^{2+}$ of A549 cells. When A549 cells were treated with Tan-IIA $(2 \mu \mathrm{g} / \mathrm{ml})$ for different durations $(0$, 6,12 and $24 \mathrm{~h}$ ). The $\mathrm{Ca}^{2+}$ was evaluated as described in Materials and methods. The increasing $\mathrm{Ca}^{2+}$ concentration percentages were $0.65 \pm 0.11$, $1.02 \pm 1.00,2.01 \pm 1.09$ and $21.21 \pm 3.01 \%$, respectively. The $\mathrm{Ca}^{2+}$ concentrations were significantly different between the Tan-IIA treated group and the control group. Increasing the time of incubation led to an increase in the concentrations of $\mathrm{Ca}^{2+}$ in the examined A549 cells. Each point is the mean \pm SD of three experiments. ${ }^{*} \mathrm{P}<0.05$.
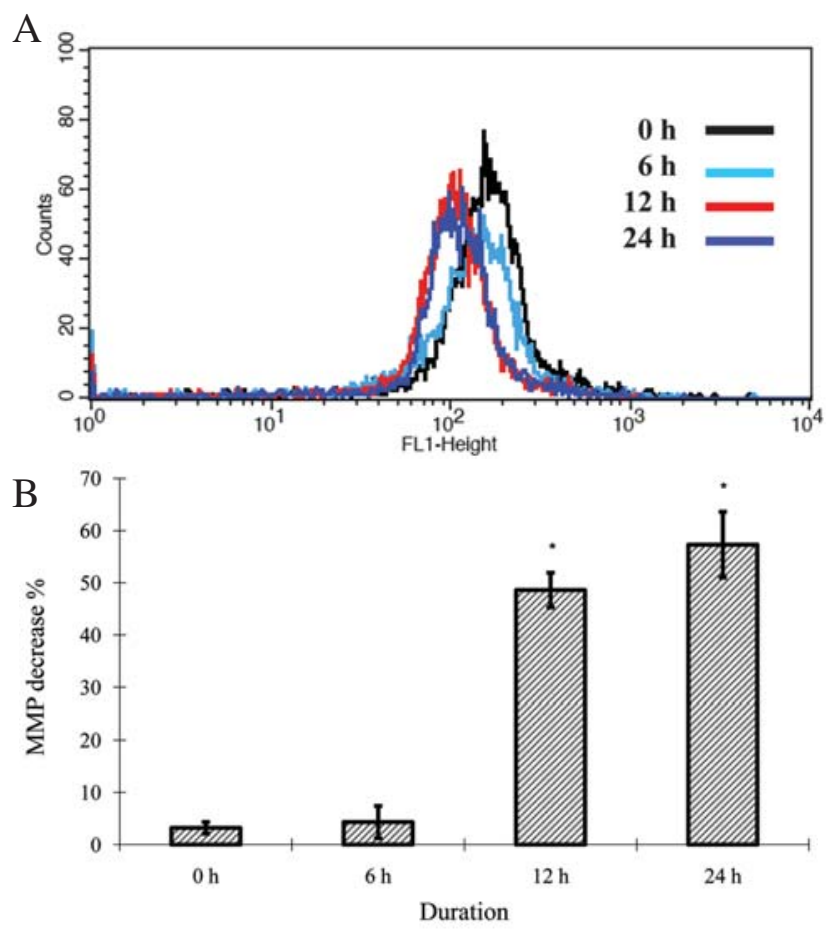

Figure 8. The effects of Tan-IIA on the MMP of A549 cells. When A549 cells were treated with Tan-IIA $(2 \mu \mathrm{g} / \mathrm{ml})$ for different durations $(0,6,12$ and $24 \mathrm{~h})$, The MMP was evaluated as described in Materials and methods. The decreasing MMP percentages were 3.21 $\pm 1.11,4.32 \pm 3.10,48.62 \pm 3.32$ and $57.33 \pm 6.30 \%$, respectively. Increasing the time of incubation led the MMP decreasing in the examined A549 cells. Each point is the mean $\pm \mathrm{SD}$ of three experiments. ${ }^{*} \mathrm{P}<0.05$

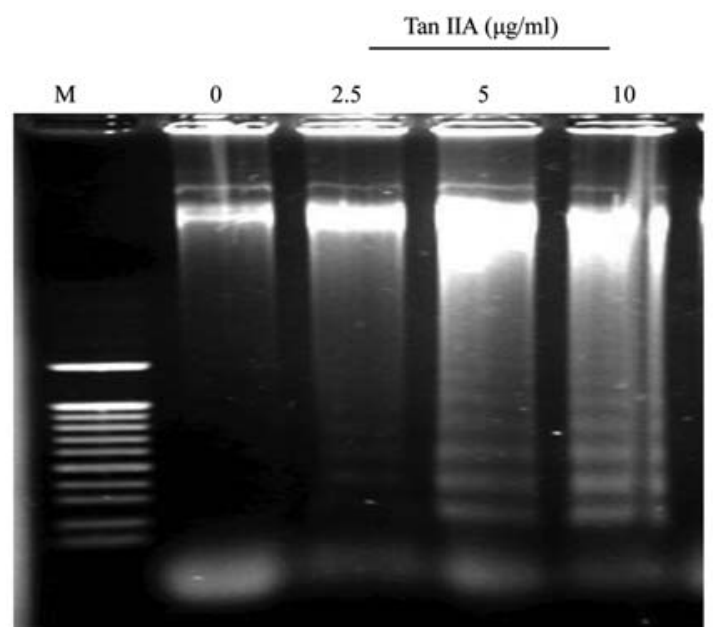

Figure 9. DNA fragmentation electrophoresis analysis was evaluated as described in Materials and methods. A549 cells were treated with Tan-IIA at the concentration of $2.5,5$ and $10 \mu \mathrm{g} / \mathrm{ml}$ for $24 \mathrm{~h}$. The multiples of fragments were significantly increased after A549 cells were treated with Tan-IIA.

to an increase of the level of ROS in the examined A549 cells (Fig. 6A and B).

Effects of Tan-IIA on the production of $\mathrm{Ca}^{2+}$ of A549 cells. When A549 cells were treated with Tan-IIA $(2 \mu \mathrm{g} / \mathrm{m})$ for different durations $(0,6,12$ and $24 \mathrm{~h})$, the $\mathrm{Ca}^{2+}$ increasing percentage concentrations were $0.65 \pm 0.11,1.02 \pm 1.00$, $2.01 \pm 1.09$ and $21.21 \pm 3.01 \%$, respectively. The $\mathrm{Ca}^{2+}$ 
concentrations were significantly different between the TanIIA treated group and the control group. Increasing the time of incubation led to an increase in the concentrations of $\mathrm{Ca}^{2+}$ in the examined A549 cells (Fig. 7A and B).

The effects of Tan-IIA on MMP in A549 cells. When A549 cells were treated with Tan-IIA $(2 \mu \mathrm{g} / \mathrm{m})$ for different durations $(0$, $6,12$ and $24 \mathrm{~h})$, the MMP decreasing percentages were $3.21 \pm 1.11,4.32 \pm 3.10,48.62 \pm 3.32$ and $57.33 \pm 6.30 \%$, respectively. Increasing the time of incubation led to the deacrease of MMP in the examined A549 cells (Fig. 8A and B).

DNA fragmentation electrophoresis analysis. The cleavage of the genomic DNA into multiples of oligonucleosomal fragments (180-200 bp) is one of the classic features of apoptosis. DNA fragmentation electrophoresis analysis was performed to investigate Tan-IIA-mediated A549 cells apoptosis. The results showed that the presentation of multiples of fragments were significantly increased after A549 cells were treated with Tan-IIA at the concentrations of 2.5, 5 and $10 \mu \mathrm{g} / \mathrm{ml}$ for $24 \mathrm{~h}$ (Fig. 9). That Tan-IIA induces apoptosis in A549 cells was confirmed.

\section{Discussion}

Our results showed that Tan-IIA induces apoptosis and inhibits proliferation in non-small cell lung cancer A549 cells in a dose- and time-dependent manner. Our Western blotting data indicated that Tan-IIA decreased expression of Bcl-2 and increased expression of p53, Bax and Cyto-c in A549 cells. This is in agreement with other reports which have demonstrated that Tan-IIA induces apoptosis in human lung cancer SPC-A-1 cells through upregulating protein expression of p53 and Bax and downregulating protein expression of Bcl-2 (20). Apoptosis is a programmed mechanism of cell death. It is well documented that mitochondrial structure and function have a close relationship with apoptosis (21). MMP decreasing induces Cyto-c release and apoptosis $(22,23)$. Overexpression of the protein $\mathrm{Bcl}-2$ prevents the decrease of MMP, but over-expression of the Bax protein decreases MMP and then induces apoptosis $(24,25)$. Our results also showed that Tan-IIA increases the induction of ROS and decreases MMP. Therefore, the pathways for Tan-IIA-induced apoptosis in human A549 cells are mitochondria-dependent. Since TanIIA may be through the induction of ROS and a higher ratio of $\mathrm{Bax} / \mathrm{Bcl}-2$, then decreasing MMP leads to Cytochrome $\mathrm{c}$ release and causes apoptosis.

\section{Acknowledgements}

This study was supported by grants CCMP95-RD-206, CCMP97-RD-011 and CCMP98-RD-102 from the Committee on Chinese Medicine and Pharmacy, Department of Health, Executive Yuan, Taiwan, R.O.C., and partially supported by the Chen-Han Foundation for Education.

\section{References}

1. Parkin DM, Pisani P and Ferlay J: Global cancer statistics. CA Cancer J Clin 49: 33-64, 1999.

2. Che AJ, Zhang JY, Li CH, Chen XF, Hu ZD and Chen XG: Separation and determination of active components in Radix Salviae miltiorrhizae and its medicinal preparations by nonaqueous capillary electrophoresis. J Sep Sci 27: 569-575, 2004.
3. Zhou L, Zuo Z and Chow MS: Danshen: an overview of its chemistry, pharmacology, pharmacokinetics, and clinical use. J Clin Pharmacol 45: 1345-1359, 2005.

4. Sun J, Tan BK, Huang SH, Whiteman M and Zhu YZ: Effects of natural products on ischemic heart diseases and cardiovascular system. Acta Pharmacol Sin 23: 1142-1151, 2002.

5. Fish JM, Welchons DR, Kim YS, Lee SH, Ho WK and Antzelevitch C: Dimethyl lithospermate B, an extract of Danshen, suppresses arrhythmogenesis associated with the Brugada syndrome. Circulation 113: 1393-1400, 2006.

6. Chang PN, Mao JC, Huang SH, Ning L, Wang ZJ, On T, Duan W and Zhu YZ: Analysis of cardioprotective effects using purified Salvia miltiorrhiza extract on isolated rat hearts. J Pharmacol Sci 101: 245-249, 2006.

7. Jang SI, Kim HJ, Kim YJ, Jeong SI and You YO: Tanshinone IIA inhibits LPS-induced NF-kappaB activation in RAW 264.7 cells: possible involvement of the NIK-IKK, ERK1/2, p38 and JNK pathways. Eur J Pharmacol 542: 1-7, 2006.

8. Li W, Li J, Ashok M, Wu R, Chen D, Yang L, Yang H, Tracey KJ, Wang P, Sama AE and Wang H: A cardiovascular drug rescues mice from lethal sepsis by selectively attenuating a late-acting proinflammatory mediator, high mobility group box 1 . J Immunol 78: 3856-3864, 2007

9. Lin R, Wang WR, Liu JT, Yang GD and Han CJ: Protective effect of tanshinone IIA on human umbilical vein endothelial cell injured by hydrogen peroxide and its mechanism. J Ethnopharmacol 108: 217-222, 2006.

10. Wang AM, Sha SH, Lesniak W and Schacht J: Tanshinone (Salviae miltiorrhizae extract) preparations attenuate aminoglycoside-induced free radical formation in vitro and ototoxicity in vivo. Antimicrob Agents Chemother 47: 1836-1841, 2003.

11. Liu JJ, Lin DJ, Liu PQ, Huang M, Li XD and Huang RW: Induction of apoptosis and inhibition of cell adhesive and invasive effects by tanshinone IIA in acute promyelocytic leukemia cells in vitro. J Biomed Sci 13: 813-823, 2006.

12. Su CC and Lin YH: Tanshinone IIA inhibits human breast cancer cells through increased $\mathrm{Bax}$ to $\mathrm{Bcl}-\mathrm{xL}$ ratios. Int $\mathrm{J}$ Mol Med 22: 357-361, 2008.

13. Su CC, Chen GW, Kang JC and Chan MH: Growth inhibition and apoptosis induction by tanshinone IIA in human colon adenocarcinoma cells. Planta Med 74: 1357-1362, 2008.

14. Yuan SL, Wei YQ, Wang XJ, Xiao F, Li SF and Zhang J: Growth inhibition and apoptosis induction of tanshinone II-A on human hepato-cellular carcinoma cells. World J Gastroenterol 10: 2024-2028, 2004

15. Mossman T: Rapid colorimetric assay for cellular growth and survival: application to proliferation and cytotoxicity assays. J Immunol Methods 65: 55-63, 1983.

16. Li TM, Chen GW, Su CC, Lin JG, Yeh CC, Cheng KC and Chung JG: Ellagic acid induced p53/p21 expression, G1 arrest and apoptosis in human bladder cancer T24 cells. Anticancer Res 25: 971-979, 2005

17. Su CC, Lin JG, Li TM, et al: Curcumin-induced apoptosis of human colon cancer colo 205 cells through the production of ROS, $\mathrm{Ca}^{2+}$ and the activation of caspase- 3 . Anticancer Res 26 : 4379-4389, 2006.

18. Su CC, Chen GW and Lin JG: Growth inhibition and apoptosis induction by tanshinone I in human colon cancer Colo 205 cells Int J Mol Med 22: 613-618, 2008.

19. Chung JG: Effects of the butylated hydroxyanisole (BHA) and butylated hydroxytoluene (BHT)on the acetylation of 2-aminofluorene and DNA-2-aminofluorene adducts in the rat. Toxicol Sci 51: 202-210, 1999.

20. Wang JC: DNA topoisomerases. Annu Rev Biochem 65: 635-692, 1996.

21. Slichenmyer WJ, Rowinsky EK, Donehower RC and Kaufmann SH: The current status of camptothecin analogues as antitumor agents. J Natl Cancer Inst 85: 271-291, 1993.

22. Zamzami N, Susin SA, Marchetti P, Hirsch T, Gomez-Monterrey I, Castedo M and Kroemer G: Mitochondrial control of nuclear apoptosis. J Exp Med 183: 1533-1544, 1996.

23. Ledgerwood EC and Morison IM: Targeting the apoptosome for cancer therapy. Clin Cancer Res 15: 420-424, 2009.

24. Pommier Y, Leteurtre F, Fesen MR, Fujimori A, Bertrand R, Solary E, Kohlhagen G and Kohn KW: Cellular determinants of sensitivity and resistance to DNA topoisomerase inhibitors. Cancer Invest 12: 530-542, 1994.

25. He JT, Zhou QH, Yuan SL, Wang YP, Chen XO and Qin JJ: Apoptosis-inducing effect of Tanshinone and its molecular mechanism on human lung cancer cells. J. Chin J Lung Cancer 5: 257-259, 2002. 